Biological and Clinical Sciences Research Journal

ISSN: 2708-2261

www.bcsrj.com

DOI: https://doi.org/10.54112/bcsrj.v2020i1.25

Biol. Clin. Sci. Res. J., Volume, 2020: 25

Original Research

MEDEYE

\title{
EVALUATION OF MAIZE SEEDLING TRAITS UNDER SALT STRESS \\ EVALUATION OF MAIZE SEEDLING TRAITS UNDER SALT STRESS
}

\author{
NASEEM S, *ALI Q, MALIK A
}

\author{
Institute of Molecular Biology and Biotechnology, The university of Lahore, Lahore, Pakistan \\ Corresponding author: saim1692@gamil.com
}

(Received, $4^{\text {th }}$ March 2020, Revised $5^{\text {th }}$ September 2020, Published $16^{\text {nd }}$ September 2020)

\begin{abstract}
Maize is an important cereal crop lies at third after wheat and rice in Pakistan. It is very sensitive to salt, heat, drought, cold and heavy metal stresses. To evaluate the effects of salt ( $\mathrm{NaCl}$ ) on maize plant we have conducted a research experiment in the Green House of Institute of Molecular Biology and Biotechnology, The University of Lahore, Lahore. We select hybrid P1429, P5971 and P6103 of Maize to access the effect of different concentrations of $\mathrm{NaCl}$ stress included control, 0.25Molar $\mathrm{NaCl}$, 0.5Molar $\mathrm{NaCl}$, 0.75Molar $\mathrm{NaCl}$, and 1 Molar $\mathrm{NaCl}$ applications. The pots were filled with pure sand and seeds of each hybrid were sown in each pot and were let to germinate. After 7 days of germination the data was collected for leaf length, root length, shoot length and root/shoot length ratio. The pots were then given the treatment and data of above mentioned traits was recorded, the application of treatments and data recording were repeated 4 times. The data recorded (4 times each after one week) was subjected to pooled analysis of variance to find significant differences among hybrids and treatments. The result of our study showed that there were significant correlation among root length, shoot length and leaf length of seedlings, from average performance of hybrid P6103 was better as compared with other two hybrids under higher salt stress conditions. It was suggested from our study that the hybrid P6103 may be used as salt tolerance hybrids for improving grain and fodder yield of maize under salt stress condition.
\end{abstract}

Keywords: maize, salt stress, $\mathrm{NaCl}$, root length, shoot length

\section{Introduction}

Maize (Corn) belongs to the grass family and has been grown throughout the world. It is an important cereal crop after wheat and rice. Among them the maize crop has more ability in term of production per hectare. The increase in yield requires a continuous increase in supply for improved and enhanced germplasm for improving the fodder and grain yield and productivity of corn plant. The growing area of corn has been decreasing through every year while very low expectation of increasing area and production in coming future (Ali et al., 2013; Ashraf et al., 2020). Therefore, there is an urgent requirement or need for vertical or continuous increase for fodder and grain yield/hectare for insuring the household and livestock food and fee security throughout the world (Boomsma et al., 2009; Cakir, 2004). However, the global warming changing, with a result for climatic change, causing a negative effect on corn crop grain yield and productivity which is increasing the food shortage and insecurity, although it has been noted that the current climatic effects caused a change in the relation for maize has become inconclusive along with the model dependent in corn growth, development, grain productivity and yield (Ali et al.,
2011; Buckler et al., 2009; Edreira and Otegui, 2012). It has been found form various research works on climatic changing effects that the increase in temperature and rainfall are interlinked with each other, the increase in the temperature is also causing drought along with salt stress in the temperate, subtropical and tropical regions of world, there is an average increase in temperature up to $3-4^{\circ} \mathrm{C}$ till end of 21th century throughout the world and South East Asia continent (Buckler et al., 2009; Mupangwa et al., 2007; Mustafa et al., 2013; Saif-ul-malook et al., 2014).

\section{Materials and Methods}

The seeds of hybrid P1429, P5971 and P6103 were sown in pots. The base of the pots were covered with soil and the rest was filled with sand in each plastic pot about 8 to 10 seeds were sown in the sand at the depth of $3 \mathrm{~cm}$. the pots with both given conditions were irrigated with tap water initially. Treatment was given with different levels of $\mathrm{NaCl}$ (0.25Molar, 0.5Molar, 0.75Molar, 1Molar) and control. Data collection: the sampling of the plants was done at the time of harvesting. After every 7 days of treatment, 2 plants from each pot were randomly harvested carefully and various factors such as leaf length, root length, shoot length and root/shoot length ratio were 
recorded. The data was analyzed for analysis of variance by using SPSS 23.1 version.

\section{Result and discussions \\ Leaf length}

The result we obtain from our finding and calculation showed that there was a significant difference between the treatments of different concentration of $\mathrm{NaCl}$ stress (Table 1). The coefficient of variance was lower which indicated that the results were reliable and accurate which may be used for further analysis and may be used to select genotypes to improve yield and increase their resistance against the stress. The average length of leaf was recorded as $10.8867 \pm 0.5505 \mathrm{~cm}$ under different treatments. The average performance of all three hybrids was higher for control $(13.6333 \pm 0.69602 \mathrm{~cm})$ followed by 1 Molar $\mathrm{NaCl}(12.00 \pm 0.57735 \mathrm{~cm})$. The results from table 2 showed that the performance of hybrid P6103 was higher for treatments of $\mathrm{NaCl}$ with higher concentrations $0.5 \mathrm{Molar} \mathrm{NaCl}, 0.75 \mathrm{Molar} \mathrm{NaCl}$ and 1 Molar $\mathrm{NaCl}$ as compared with other hybrids which showed better performance on lower concentrations of salt stress. The average leaf increase it indicated that the growth of leaf is good under the different concentrations of $\mathrm{NaCl}$ treatments and it show that they show tolerance against the different concentrations of stress and promote growth and yield of plant (Ali et al., 2016; Ali et al., 2014; Chai et al., 2016; Edreira and Otegui, 2012).

Table 1. Mean performance of maize genotypes for leaf length under different salt concentrations

\begin{tabular}{|c|c|c|c|c|c|c|c|}
\hline Treatments & Mean & $\begin{array}{l}\text { Std. } \\
\text { Deviation }\end{array}$ & $\begin{array}{l}\text { Std. } \\
\text { Error }\end{array}$ & $\begin{array}{l}95 \% \text { Confid } \\
\text { for Mean } \\
\text { Lower limit }\end{array}$ & $\begin{array}{l}\text { ce Interval } \\
\text { Upper limit }\end{array}$ & Minimum & Maximum \\
\hline Control & 13.6333 & 1.20554 & 0.69602 & 10.6386 & 16.6281 & 12.50 & 14.90 \\
\hline 0.25 Molar NaCl & 8.0000 & 1.32288 & 0.76376 & 4.7138 & 11.2862 & 6.50 & 9.00 \\
\hline 0.5 Molar $\mathrm{NaCl}$ & 10.7333 & 1.12398 & 0.64893 & 7.9412 & 13.5255 & 9.50 & 11.70 \\
\hline 0.75 Molar NaCl & 10.0667 & 0.40415 & 0.23333 & 9.0627 & 11.0706 & 9.70 & 10.50 \\
\hline 1Molar NaCl & 12.0000 & 1.00000 & 0.57735 & 9.5159 & 14.4841 & 11.00 & 13.00 \\
\hline Grand Mean & 10.8867 & & 0.5505 & & & & \\
\hline $\begin{array}{l}\text { Coefficient of } \\
\text { variation }\end{array}$ & 9.67 & & & & & & \\
\hline
\end{tabular}

\begin{tabular}{lccc}
\multicolumn{4}{c}{ Table 1a. } \\
\hline Treatments & P1429 & P5971 & P6103 \\
\hline Control & 8.0000 & & \\
0.25 Molar NaCl & 10.0667 & 10.0667 & \\
0.5 Molar NaCl & 10.7333 & 10.7333 & 10.7333 \\
0.75 Molar NaCl & & 12.0000 & 12.0000 \\
1Molar NaCl & & & 13.6333 \\
Sig. p<0.05 & 0.110 & 0.353 & 0.085 \\
\hline
\end{tabular}

\section{Shoot length}

The results have shown that there was significant difference between the treatments of different concentration of $\mathrm{NaCl}$ stress (Table 2). The coefficient of variance was lower it means the result were reliable and accurate which indicated that we used it in further analysis for selection of maize genotypes for yield and enhanced tolerance against salt stress. The average length of shoot was recorded as $10.4800 \pm 0.77393 \mathrm{~cm}$ under different treatments. The average performance of all three hybrids was higher for control $(12.00 \pm 0.57735 \mathrm{~cm})$ followed by 1Molar $\mathrm{NaCl}(14.6667 \pm 1.20185 \mathrm{~cm})$. The results from table 2a showed that the performance of hybrid $\mathrm{P} 6103$ was higher for treatments of $\mathrm{NaCl}$ with higher concentrations 0.5 Molar $\mathrm{NaCl}$ and 0.75 Molar $\mathrm{NaCl}$ as compared with other hybrids which showed better performance on lower concentrations of salt stress. The average shoot increase it indicated that the growth of leaf is good under the different concentrations of $\mathrm{NaCl}$ treatments and it show that they show tolerance against the different concentrations of stress and promote growth and yield of plant (Ali et al., 2015; Ali et al., 2012; de Azevedo Neto et al., 2006; Farre and Faci, 2006; Kanwal et al., 2019).

Table 2. Mean performance of maize genotypes for shoot length under different salt concentrations

\begin{tabular}{|c|c|c|c|c|c|c|c|}
\hline \multirow[t]{2}{*}{ Treatments } & \multirow[t]{2}{*}{ Mean } & \multirow[t]{2}{*}{$\begin{array}{l}\text { Std. } \\
\text { Deviation }\end{array}$} & \multirow[t]{2}{*}{$\begin{array}{l}\text { Std. } \\
\text { Error }\end{array}$} & \multicolumn{2}{|c|}{$\begin{array}{l}\text { 95\% Confidence Interval } \\
\text { for Mean }\end{array}$} & \multirow[t]{2}{*}{ Minimum } & \multirow[t]{2}{*}{ Maximum } \\
\hline & & & & Lower limit & Upper limit & & \\
\hline Control & 12.0000 & 1.00000 & 0.57735 & 9.5159 & 14.4841 & 11.00 & 13.00 \\
\hline 0.25 Molar $\mathrm{NaCl}$ & 6.8333 & 1.25831 & 0.72648 & 3.7075 & 9.9591 & 5.50 & 8.00 \\
\hline 0.5 Molar $\mathrm{NaCl}$ & 8.5000 & .50000 & 0.28868 & 7.2579 & 9.7421 & 8.00 & 9.00 \\
\hline
\end{tabular}

[Citation: Naseem, S., Ali, Q., Malik, A. (2020). Evaluation of maize seedling traits under salt stress. Biol. Clin. Sci. Res. J., 2020: 25 doi: https://doi.org/10.54112/bcsrj.v2020i1.25] 


\begin{tabular}{llllllll}
\hline $\begin{array}{l}\text { 0.75 Molar NaCl } \\
\text { 1Molar NaCl }\end{array}$ & 10.4000 & .36056 & 0.20817 & 9.5043 & 11.2957 & 10.00 & 10.70 \\
$\begin{array}{l}\text { Grand Mean } \\
\text { Coefficient of } \\
\text { variation }\end{array}$ & 14.6667 & 2.08167 & 1.20185 & 9.4955 & 19.8378 & 13.00 & 17.00 \\
\hline
\end{tabular}

\begin{tabular}{lccc}
\multicolumn{4}{c}{ Table 2a. Means for group in homogeneous subsets for shoot length } \\
\hline Treatments & P1429 & P5971 & P6103 \\
\hline Control & 5.3000 & & \\
0.25 Molar NaCl & 6.5000 & 6.5000 & 7.5000 \\
$\mathbf{0 . 5}$ Molar NaCl & & 7.5000 & 8.1667 \\
$\mathbf{0 . 7 5}$ Molar NaCl & & & \\
1Molar NaCl & & & 0.691 \\
Sig. p p $\mathbf{0 . 0 5}$ & 0.197 & 0.340 & $0.75 M$ \\
\hline
\end{tabular}

\section{Root length}

The results showed significant differences between the treatments of different concentration of $\mathrm{NaCl}$ stress. The average length of root was recorded that $(10.1533 \pm 0.62821 \mathrm{~cm})$ under different treatments (Table 3). The average performance of all three hybrids was higher for control $(12.1667 \pm 0.56862 \mathrm{~cm})$ followed by $0.75 \mathrm{Molar} \mathrm{NaCl}(12.400 \pm 0.79373 \mathrm{~cm})$ and 1 Molar $\mathrm{NaCl}(10.40 \pm 0.65574 \mathrm{~cm})$. The results from table $3 \mathrm{a}$ showed that the performance of hybrid P6103 was higher for treatments of $\mathrm{NaCl}$ with higher

fean performance of maiz concentrations $0.75 \mathrm{Molar} \mathrm{NaCl}$ and $1 \mathrm{Molar} \mathrm{NaCl}$ as compared with other hybrids which showed better performance on lower concentrations of salt stress. The average root length increase it indicated that the growth of root is good under the different concentrations of $\mathrm{NaCl}$ treatments and it show that they show tolerance against the different concentrations of stress and promote growth and yield of plant (Aaliya et al., 2016; Abbas et al., 2016; Ali et al., 2017; Farooq et al., 2015; Karahara et al., 2004; Sheng et al., 2008).

\begin{tabular}{|c|c|c|c|c|c|c|c|}
\hline Treatments & Mean & $\begin{array}{l}\text { Std. } \\
\text { Deviation }\end{array}$ & $\begin{array}{l}\text { Std. } \\
\text { Error }\end{array}$ & \multicolumn{2}{|c|}{$\begin{array}{l}95 \% \text { Confidence Interval } \\
\text { for Mean }\end{array}$} & Minimum & Maximum \\
\hline Control & 9.8000 & 0.40000 & 0.23094 & 8.8063 & 10.7937 & 9.40 & 10.20 \\
\hline 0.25 Molar $\mathrm{NaCl}$ & 6.0000 & 0.30000 & 0.17321 & 5.2548 & 6.7452 & 5.70 & 6.30 \\
\hline 0.5 Molar $\mathrm{NaCl}$ & 12.1667 & 0.56862 & 0.32830 & 10.7541 & 13.5792 & 11.70 & 12.80 \\
\hline 0.75 Molar NaCl & 12.4000 & 0.79373 & 0.45826 & 10.4283 & 14.3717 & 11.50 & 13.00 \\
\hline 1Molar NaCl & 10.4000 & 0.65574 & 0.37859 & 8.7710 & 12.0290 & 9.70 & 11.00 \\
\hline Grand Mean & 10.1533 & & 0.62821 & & & & \\
\hline $\begin{array}{l}\text { Coefficient of } \\
\text { variation }\end{array}$ & 9.973 & & & & & & \\
\hline
\end{tabular}

Table 3a. Means for group in
Treatments
Control
$\mathbf{0 . 2 5}$ Molar NaCl
$\mathbf{0 . 5}$ Molar NaCl
$\mathbf{0 . 7 5}$ Molar NaCl
$\mathbf{1 M o l a r ~ N a C l}$
Sig. p<0.05
length ratio
showed significant differences between the
of different concentration of NaCl stress
The coefficient of variance is lower it
result is reliable and accurate it indicate
ed it in future to improve their yield and
their resistance against the stress. The
shoot weight was recorded that $(0.6273 \pm$
under different treatments. The average
length ratio increased which indicated that
P6103

9.8000

10.4000

0.795

12.1667

12.4000

the growth of leaf, roots and shoot was good under the different concentrations of $\mathrm{NaCl}$ treatments which showed tolerance against the different concentrations of stress and promote growth and yield of maize plant. The average performance of hybrid P6103 was better under the treatments of .25Molar $\mathrm{NaCl}$, 0.5 Molar $\mathrm{NaCl}$ and 1 Molar $\mathrm{NaCl}$ concentration as compared with other maize hybrids. The different comparison of maize hybrids show that the root/shoot length ratio of seedlings was lower under 0.25 Molar

[Citation: Naseem, S., Ali, Q., Malik, A. (2020). Evaluation of maize seedling traits under salt stress. Biol. Clin. Sci. Res. J., 2020: 25 doi: https://doi.org/10.54112/bcsrj.v2020i1.25] 
$\mathrm{NaCl}$ is $(0.2800)$ followed by 0.5 Molar $\mathrm{NaCl}$ (0.4567), control (0.7000). $0.75 \mathrm{M} \mathrm{NaCl}(0.8000)$ while highest under 1Molar $\mathrm{NaCl}$ (0.9000) concentration. The result indicated that the effect of various salt concentrations affected the plants but if the stress concentration is lower than the growth of leaves is higher it means the concentrations effect the growth but improving some traits it can provide more tolerance in future (Mazhar et al., 2020; Shu and Liu, 2001; Tahir et al., 2020; Zubair et al., 2016).

Table 4. Mean performance of maize genotypes for root/shoot length ratio under different salt concentrations

\begin{tabular}{|c|c|c|c|c|c|c|c|}
\hline Treatments & Mean & $\begin{array}{l}\text { Std. } \\
\text { Deviation }\end{array}$ & $\begin{array}{l}\text { Std. } \\
\text { Error }\end{array}$ & \multicolumn{2}{|c|}{$\begin{array}{l}95 \% \text { Confidence Interval } \\
\text { for Mean }\end{array}$} & Minimum & Maximum \\
\hline Control & 0.7000 & 0.10000 & 0.05774 & 0.4516 & 0.9484 & 0.60 & 0.80 \\
\hline 0.25 Molar NaCl & 0.2800 & 0.07211 & 0.04163 & 0.1009 & 0.4591 & 0.20 & 0.34 \\
\hline 0.5 Molar $\mathrm{NaCl}$ & 0.4567 & 0.14012 & 0.08090 & 0.1086 & 0.8047 & 0.30 & 0.57 \\
\hline 0.75 Molar NaCl & 0.8000 & 0.10000 & 0.05774 & 0.5516 & 1.0484 & 0.70 & 0.90 \\
\hline 1Molar NaCl & 0.9000 & 0.10000 & 0.05774 & 0.6516 & 1.1484 & 0.80 & 1.00 \\
\hline Grand Mean & 0.6273 & & 0.06500 & & & & \\
\hline $\begin{array}{l}\text { Coefficient of } \\
\text { variation }\end{array}$ & 10.103 & & & & & & \\
\hline
\end{tabular}

\begin{tabular}{lccc}
\multicolumn{2}{c}{ Table 4a. Means for group in homogeneous subsets for root/shoot length } & P6103 \\
\hline Treatments & P1429 & P5971 & \\
\hline Control & 0.2800 & & \\
0.25 Molar NaCl & 0.4567 & 0.4567 & 0.7000 \\
0.5 Molar NaCl & & 0.7000 & 0.8000 \\
0.75 Molar NaCl & & & 0.9000 \\
1Molar NaCl & & & 0.312 \\
Sig. p<0.05 & 0.422 & 0.167 &
\end{tabular}

The results from table 5 indicated that there was that the selection of maize genotypes for salt stress positive and significant correlation among all of the tolerance may be helpful to improve grain and fodder studied traits. Root length and shoot length showed yield of maize under slat stress conditions. strong and significant correlation which indicated

Table 4. Pooled correlation among different traits of maize under drought stress conditions

\begin{tabular}{llll}
\hline Traits & Shoot length & Root length & Leaf length \\
\hline Root length & $0.8019^{*}$ & & \\
Leaf length & $0.6701^{*}$ & 0.2307 & \\
Root/shoot length & $0.4503^{*}$ & -0.2250 & $0.4914^{*}$
\end{tabular}

\section{Conflict of interest}

The authors declared absence of any type of conflict of interest in manuscript publication

\section{References}

Aaliya, K., Qamar, Z., Ahmad, N. I., Ali, Q., Munim, F. A., and Husnain, T. (2016). Transformation, evaluation of gtgene and multivariate genetic analysis for morphophysiological and yield attributing traits in Zea mays. Genetika 48, 423-433.

Abbas, H. G., Mahmood, A., and Ali, Q. (2016). Zero tillage: a potential technology to improve cotton yield. Genetika 48, 761-776.

Ali, F., Ahsan, M., Ali, Q., and Kanwal, N. (2017). Phenotypic stability of Zea mays grain yield and its attributing traits under drought stress. Frontiers in plant science 8, 1397.
Ali, F., Kanwal, N., Ahsan, M., Ali, Q., Bibi, I., and Niazi, N. K. (2015). Multivariate analysis of grain yield and its attributing traits in different maize hybrids grown under heat and drought stress. Scientifica 2015.

Ali, Q., Ahsan, M., Ali, F., Aslam, M., Khan, N. H., Munzoor, M., Mustafa, H. S. B., and Muhammad, S. (2013). Heritability, heterosis and heterobeltiosis studies for morphological traits of maize (Zea mays L.) seedlings. Advancements in Life sciences 1.

Ali, Q., Ahsan, M., Kanwal, N., Ali, F., Ali, A., Ahmed, W., Ishfaq, M., and Saleem, M. (2016). Screening for drought tolerance: comparison of maize hybrids under water deficit condition. Advancements in Life Sciences 3, 51-58.

[Citation: Naseem, S., Ali, Q., Malik, A. (2020). Evaluation of maize seedling traits under salt stress. Biol. Clin. Sci. Res. J., 2020: 25 doi: https://doi.org/10.54112/bcsrj.v2020i1.25] 
Ali, Q., Ahsan, M., Tahir, M. H. N., and Basra, S. M. A. (2012). Genetic evaluation of maize (Zea mays L.) accessions for growth related seedling traits. International Journal for Agro Veterinary and Medical Sciences 6, 164-172.

Ali, Q., Ali, A., Ahsan, M., Nasir, I. A., Abbas, H. G., and Ashraf, M. A. (2014). Linex Tester analysis for morpho-physiological traits of Zea mays L seedlings. Advancements in Life sciences 1, 242-253.

Ali, Q., Hammad, M., Tahir, N., Ahsan, M., Basra, S. M. A., Farooq, J., and Elahi, M. (2011). Correlation and path coefficient studies in maize (Zea mays L.) genotypes under $40 \%$ soil moisture contents. African Journal of Bacteriology Research 3, 77-82.

Ashraf, A., Rashid, M., Ali, Q., and Malik, A. (2020). Genetic Advances and Heritability Analysis for Seedling Growth Traits in Zea mays under Heavy Metal Stress. Genetics and Molecular Research 19.

Boomsma, C. R., Santini, J. B., Tollenaar, M., and Vyn, T. J. (2009). Maize morphophysiological responses to intense crowding and low nitrogen availability: An analysis and review. Agronomy Journal 101, 1426-1452.

Buckler, E. S., Holland, J. B., Bradbury, P. J., Acharya, C. B., Brown, P. J., Browne, C., Ersoz, E., Flint-Garcia, S., Garcia, A., and Glaubitz, J. C. (2009). The genetic architecture of maize flowering time. Science 325, 714-718.

Cakir, R. (2004). Effect of water stress at different development stages on vegetative and reproductive growth of corn. Field Crops Research 89, 1-16.

Chai, Q., Gan, Y., Zhao, C., Xu, H.-L., Waskom, R. M., Niu, Y., and Siddique, K. H. (2016). Regulated deficit irrigation for crop production under drought stress. A review. Agronomy for sustainable development 36, 3.

de Azevedo Neto, A. D., Prisco, J. T., Enéas-Filho, J., de Abreu, C. E. B., and Gomes-Filho, E. (2006). Effect of salt stress on antioxidative enzymes and lipid peroxidation in leaves and roots of salt-tolerant and salt-sensitive maize genotypes. Environmental and Experimental Botany 56, 87-94.

Edreira, J. I. R., and Otegui, M. E. (2012). Heat stress in temperate and tropical maize hybrids: Differences in crop growth, biomass partitioning and reserves use. Field Crops Research 130, 87-98.

Farooq, M., Hussain, M., Wakeel, A., and Siddique, K. H. (2015). Salt stress in maize: effects, resistance mechanisms, and management. A review. Agronomy for Sustainable Development 35, 461-481.

Farre, I., and Faci, J. M. (2006). Comparative response of maize (Zea mays L.) and sorghum (Sorghum bicolor L. Moench) to deficit irrigation in a Mediterranean environment. Agricultural water management 83, 135-143.

Kanwal, N., Ali, F., Ali, Q., and Sadaqat, H. A. (2019). Phenotypic tendency of achene yield and oil contents in sunflower hybrids. Acta Agriculturae Scandinavica, Section B-Soil \& Plant Science 69, 690-705.

Karahara, I., Ikeda, A., Kondo, T., and Uetake, Y. (2004). Development of the Casparian strip in primary roots of maize under salt stress. Planta 219, 41-47.

Mazhar, T., Ali, Q., and Malik, M. S. R. A. (2020). Effects of salt and drought stress on growth traits of Zea mays seedlings. Life Science Journal 17.

Mupangwa, W., Twomlow, S., Walker, S., and Hove, L. (2007). Effect of minimum tillage and mulching on maize (Zea mays L.) yield and water content of clayey and sandy soils. Physics and chemistry of the earth, parts A/B/C 32, 1127-1134.

Mustafa, H. S. B., Ahsan, M., Aslam, M., Ali, Q., Bibi, T., and Mehmood, T. (2013). Genetic variability and traits association in maize (Zea mays L.) accessions under drought stress. Journal of Agricultural Research (03681157) $\mathbf{5 1 .}$

Saif-ul-malook, M. A., Ali, Q., and Mumtaz, A. (2014). Inheritance of yield related traits in maize (Zea mays) under normal and drought conditions. Nat Sci 12, 36-49.

Sheng, M., Tang, M., Chen, H., Yang, B., Zhang, F., and Huang, Y. (2008). Influence of arbuscular mycorrhizae on photosynthesis and water status of maize plants under salt stress. Mycorrhiza 18, 287-296.

Shu, L., and Liu, Y. (2001). Effects of silicon on growth of maize seedlings under salt stress. Agro-Environmental Protection 20, 38-40.

Tahir, M., Rashid, M., Ali, Q., and Malik, A. (2020). Evaluation of Genetic Variability in Wheat and Maize under Heavy Metal and Drought Stress. Genetics and Molecular Research 19.

[Citation: Naseem, S., Ali, Q., Malik, A. (2020). Evaluation of maize seedling traits under salt stress. Biol. Clin. Sci. Res. J., 2020: 25 doi: https://doi.org/10.54112/bcsrj.v2020i1.25] 
Zubair, M., Shakir, M., Ali, Q., Rani, N., Fatima, N., Farooq, S., Shafiq, S., Kanwal, N., Ali, F., and Nasir, I. A. (2016). Rhizobacteria and phytoremediation of heavy metals. Environmental Technology Reviews 5, 112119.

\section{(c) (7) (5)}

Open Access This article is licensed under a Creative Commons Attribution 4.0 International License, which permits use, sharing, adaptation, distribution and reproduction in any medium or format, as long as you give appropriate credit to the original author(s) and the source, provide a link to the Creative Commons licence, and indicate if changes were made. The images or other third party material in this article are included in the article's Creative Commons licence, unless indicated otherwise in a credit line to the material. If material is not included in the article's Creative Commons licence and your intended use is not permitted by statutory regulation or exceeds the permitted use, you will need to obtain permission directly from the copyright holder. To view a copy of this licence, visit http://creativecommons.org/licen ses/by/4.0/.

(C) The Author(s) 2021

[Citation: Naseem, S., Ali, Q., Malik, A. (2020). Evaluation of maize seedling traits under salt stress. Biol. Clin. Sci. Res. J., 2020: 25 doi: https://doi.org/10.54112/bcsrj.v2020i1.25] 